Claudia Gärtner (2020), Klima, Corona und das Christentum. Religiöse Bildung für nachhaltige Entwicklung in einer verwundeten Welt, Bielefeld: Transcript Verlag, pp. 196, ISBN 9783839454756 , € 29,00.

Dit boek is geschreven voor de educatieve context van Duitsland waarin confessioneelchristelijk godsdienstonderwijs de norm is maar daarnaast de eerste overwegingen gaan in de richting van oecumenisch godsdienstonderwijs. De christelijke theologie is het vanzelfsprekende referentiekader voor godsdienstlessen in Duitsland en Claudia Gärtner neemt in haar boek dan ook expliciet een theologisch perspectief in. In de christelijke theologie wordt religie niet enkel als privézaak opgevat, maar heeft religie ook een publieke en politieke dimensie. Het boek van Gärtner sluit aan bij deze dimensie van het christendom en biedt een nieuw ontwerp voor politiek-religieuze educatie voor duurzame ontwikkeling in Duitsland.

In het inleidend hoofdstuk beschrijft Gärtner het centrale probleem waarmee haar boek zich bezighoudt, namelijk de observatie dat de tegenwoordige tijd als een tijd van multiple crisis (migratie, klimaat, corona) begrepen kan worden. Gärtner pleit voor samenwerking tussen wetenschap, politiek, samenleving, economie, cultuur en religie om adequate antwoorden op deze crisis te vinden. De ondertitel van het boek, "Religieuze educatie voor duurzame ontwikkeling in een verwonde wereld", geeft aan in welke richting de auteur naar oplossingen zoekt. Het kernbegrip hierbij is duurzaamheid. Onder duurzaam handelen verstaat Gärtner een levensvorm en een wijze van economie bedrijven die met de natuur meewerkt. Duurzaam handelen betekent dat iedereen overal en steeds opnieuw aan dit handelen deel kan nemen en het kan herhalen. Uitdrukkelijk sluit Gärtner aan op de zeventien duurzaamheidsdoelen die 2016 door de Verenigde Naties zijn aangenomen. Religieuze educatie resp. godsdienstonderwijs voor een duurzame ontwikkeling dient volgens haar de verwonding van de wereld bloot te leggen, kritisch te kijken naar het handelen van tegenwoordige generaties en leerlingen ertoe te bekwamen ook in toekomst als vrije mensen via democratisch en solidair handelen zelf over het eigen leven te kunnen beslissen. Omdat het christendom niet alleen een kritisch potentiaal tegenover het gangbare biedt maar tegelijk ook deel uitmaakt van de verwonde wereld, en deze deels mee heeft veroorzaakt, is ook een kritische reflectie op religieuze tradities nodig. Duidelijk moge zijn dat Gärtner het christendom hier niet als een individuele aangelegenheid van de gelovigen beschouwt maar juist op de politieke en publieke uitstraling van deze godsdienst in de samenleving focust. Omdat er in Nederland nog maar weinig sprake is van deze politieke en publieke uitstraling van het christendom in de samenleving is het natuurlijk de vraag of het boek in ons land veel te zeggen heeft.

Het tweede hoofdstuk schetst centrale ontwikkelingen en karakteristieke kenmerken van een politiek-religieuze educatie voor duurzame ontwikkeling. Hiervoor wordt het gesprek aangegaan met de zogenaamde kritische pedagogiek die kanttekeningen plaatst 
bij machtsverhoudingen en ideologieën. Confessioneel godsdienstonderwijs vindt in Duitsland ook aan openbare scholen plaats en daarom bespreekt Gärtner in dit hoofdstuk ook in hoeverre normatief op duurzaamheid georiënteerde educatie in openbaar onderwijs gelegitimeerd kan worden en of deze oriëntatie leerlingen te veel beïnvloedt en in contrast staat met het streven om leerlingen erbij te ondersteunen zichzelf te zijn en hun eigen leven in vrijheid vorm te geven.

Het derde hoofdstuk behandelt gunstige en ongunstige factoren voor de politiekreligieuze educatie voor duurzame ontwikkeling die Gärtner bepleit. Uit psychologisch perspectief wordt de mind-behavior-gap behandeld, uit sociologisch perspectief de variabelen leeftijd, gender, milieu, samenleving en religie, en uit pedagogisch perspectief gaat het om didactisch-methodische concepten. Vanuit deze discoursen wordt duidelijk welke voorwaarden en factoren tot het welslagen van politiek-religieuze educatie voor duurzame ontwikkeling kunnen bijdragen. Het gaat hierbij met name om gezamenlijke waarden en normen, sociale interacties, emotionaliteit, een oriëntatie voor het handelen en de leefwereld, leren in projecten en experimenten alsook om een motiverende leeromgeving.

Het vierde hoofdstuk zet de politiek-religieuze educatie voor duurzame ontwikkeling in theologisch perspectief. Hierbij gaat het om behoud van de eigen logica van het godsdienstonderwijs. Zonder de pretentie een omvattende theologie van de duurzaamheid of een ecologische theologie te willen ontwerpen worden in dit hoofdstuk basale concepten en vragen uit de theologie behandeld, zoals andersheid, tijd, mens en schepping. Daarnaast gaat het in dit hoofdstuk om de vijf dimensies van religie volgens Glock die hier in een aangepaste versie van zes dimensies besproken worden (hermeneutische, spiritueelliturgische, lichamelijk-esthetische, communale, ethische en filosofische dimensies).

Het vijfde hoofdstuk ontwerpt concrete contouren van een politiek-religieuze educatie voor duurzame ontwikkeling in een verwonde wereld en noemt hiervoor zeven kenmerken. Het eerste kenmerk - georiënteerd op crisis en controversen - heeft met name betrekking op het zien van de crisis. De daarop volgende vijf theologische kenmerken - met een focus op de laatste dingen, vanuit de Bijbel en de traditie naar de toekomst kijkend, vanuit de christelijke waarden partij kiezend voor de gemarginaliseerde medemens en de uitgebuite schepping, kritisch-reflexief, en emancipatorisch - hebben betrekking op het beoordelen van de crisis. Het zevende en laatste kenmerk - op context en ervaring georiënteerd - verwijst naar het handelen in de crisis. Afsluitend plaatst dit hoofdstuk de politiek-religieuze educatie voor duurzame ontwikkeling in een aantal spanningsvelden: tussen determinisme en hoop op verandering, tussen het maatschappelijk voorgevormde en het mondige subject, tussen een in zichzelf waardevol gebeuren en diens functionaliteit, tussen normativiteit en pluraliteit, tussen tegenwoordige tijd en geanticipeerde toekomst en tussen waarheidsclaim en verdenking van ideologie.

Het zesde en laatste hoofdstuk presenteert zes thema's die exemplarisch besproken worden. (1) Kloostertuinen als vindplaatsen van duurzame praktijken laten zien hoe ook 
in steden concreet vorm gegeven kan worden aan de bevordering van biodiversiteit, ontmoeting en recreatie, gezonde voeding en zorg voor de gemarginaliseerde medemens. (2) Ecologische vastenprojecten (minder vlees, minder auto rijden, minder plastic etc.) maken duidelijk hoe een samenleving kan veranderen in een post-groei samenleving met begrenzing van het benutten van natuurlijke hulpbronnen en tevens een rechtvaardige verdeling daarvan. (3) Om beter om te leren gaan met de contingentie-ervaringen van de multiple crisis bieden kerken troost en geven ruimte aan onbegrip, thematiseren de kwetsbaarheid van mens en natuur, belichamen solidariteit en koesteren hoop op verlossing. (4) Door milieubewust reizen kunnen individuele christenen bijdragen aan de vermindering van $\mathrm{CO}_{2}$-uitstoot. Daarnaast kunnen christenen ook de structurele problemen van lange afstandsreizen aan de kaak stellen en in de politiek pleiten voor het beprijzen van de $\mathrm{CO}_{2}$-uitstoot. (5) De multiple crisis kan jonge mensen wakker schudden en aanleiding zijn om hun geleefde compassie in praktijk te brengen. (6) Bewustzijn voor de noodzaak van een betere dierenbescherming en kritische reflectie op het gangbare, deels decadente consumptiegedrag kan helpen om pandemieën in toekomst te voorkomen.

Of de professionals voor het vak levensbeschouwing in het Nederlandse schoolsysteem inspiratie kunnen putten uit dit boek valt te bezien. Het vak levensbeschouwing lijkt in ons land over het algemeen maar beperkte politiek-maatschappelijke impact te (willen) hebben. Het thema duurzaamheid is in Nederland onder jongeren trouwens veel minder present dan in Duitsland. Dit is ook af te lezen aan de relatief kleine rol die de beweging Fridays for Future in Nederland speelt. Als de universitaire opleidingen voor toekomstige leerkrachten levensbeschouwing (en andere relevante vakken) het thema duurzaamheid niet prominent op de agenda zetten, zal er vermoedelijk ook in de toekomst weinig animo voor dit thema in het Nederlandse schoolsysteem zijn.

\section{Elisabeth Hense}

(Radboud Universiteit Nijmegen)

Demeijer, Frederique (2020), Over apostolisch-zijn gesproken. Zes generaties lidmaten over de rol van het Apostolisch Genootschap in hun leven, Utrecht: Eburon, pp. 288, ISBN 97894630131612495, € 24,95.

Zoals de ondertitel van dit boek (dat ook heeft gediend als proefschrift aan de UvA) al aangeeft, gaat het om de rol van het Apostolisch Genootschap (hierna AG) in het leven van verschillende generaties lidmaten. Het AG is een van de vele takken van de rond 1830 in Engeland ontstane apostolische opwekkingsbeweging, uitmondend in de Catholic Apostolic Church. De geschiedenis van de Catholic Apostolic Church wordt gekenmerkt door conflicten - over de leer en over opvolgingskwesties - met als gevolg afsplitsingen. Ook het AG ontstond in $195^{1}$ als gevolg van een conflict, niet zozeer over de leer, maar 